\title{
NAGY SÁNDOR: A közpénz változó szerepe és funkciói
}

\begin{abstract}
Absztrakt: A közpénz fogalmának pontos meghatározása - jellemzőiből fakadóan nem könnyü feladat. Számos megközelítés született, de a komplex rendszerekben való elhelyezése még nem történt meg. A közpénz funkcióinak összegzésekor, szintetizálásakor erre is tekintettel voltam, és utaltam pár olyan jelenségre, amelyek kialakulhatnak a közösségi források megszerzésére irányuló törekvésekből.

Abstract: The accurate, precise definition of public money - due to its special characteristics - is not an easy task. Several approachas have been appearing, but the insertion and the emplacement of the notion into complex systems is not yet occurred. By summarizing and synthesizing the functions of public money I took it also into consideration and I referred to several phenomena or behavioral patterns, which can emerge on the basis of agents' efforts targeting the dispose and possession of community resources.

Kulcsszavak: közpénz, állami feladatok, közpénzügyi rendszer, komplexitás

Keywords: public money, government functions, public finance system, complexity
\end{abstract}

\section{Bevezetés}

A jóléti rendszerek fenntartható müködtetése napjaink megkerülhetetlen kérdésévé nőtte ki magát és az érdeklödés fókuszpontjába került mind akadémiai, mind pedig a közpénzügyi döntéshozókat illetően is. A társadalmi jólét (public welfare) megteremtése, realizációja kizárólag szélesebb kontextusba helyezve értelmezhető. Elgondolásom szerint a jólét olyan társadalmigazdasági rendszerekben alakulhat ki (materializálódhat), amelyek kellően rugalmasan képesek a külső változásokat lereagálni, rendelkeznek az ehhez szuikséges megfelelö kapacitásokkal, kreatívak és olyan innovációkat képesek előállítani, amelyek hozzảjárulnak az elöbbiek kiteljesedéséhez. További jellemzöjüknek tekinthető a nyitottság: erös szálakon kötődnek az öket körülvevő környezethez, természeti adottságokhoz. Ezek a szisztémák komplex adaptív rendszerekként írhatóak le, amelyek sajátosságainak a kezelése új szempontokat követel meg. Az állami szerepvállalás hozzájárulása ebben az összefuiggésben meghatározó. Felhatalmazásai, szabályozói jogkörének és funkcióinak gyakorlása révén központi - legalábbis ez lenne elvárható - szerepe lehet abban, hogy a területi és jogi hatálya alá tartozó entitások boldogulását, fejlődését elősegítse. Az állami feladatok finanszírozásához a közpénzügyi rendszer müködése és ezen belül a költségvetés teremt törvényi, formalizált kereteket.

A közpénz, a közjószág/közszolgáltatás, a közösségi értékteremtés, a közjó, a közpénzügyi fenntarthatóság, a kormányzás fogalmai különös fontossággal bírnak és értelmezésük/ủjraértelmezésük különösen indokolt olyan környezeti változások közepette, amelyek a közpénzügyi rendszer müködését komoly kihívások elé állítják. A felsorolt fogalmak természetesen szorosan összefüggnek, hiszen mindegyikük a közösségi finanszirozás rendszerében helyezhetöek el, illetve abból vezethetőek le. A pénzügyi-gazdasági válság, az államadósságok tendenciózus növekedése, a közszféra adaptációs és értékteremtési kényszere, valamint a fenntarthatósági szempontok egyre intenzívebb megjelenése egyre összetettebb feladatok elé állítják a közpénzügyi döntéshozókat és menedzsereket.

Írásomban alapvetően a közpénz meghatározására és funkcióira koncentrálok: feltárom és szintetizálom az eddigi releváns megközelítéseket, amelyek a fogalom fejlödéséhez hozzájárultak. Saját elképzelésemet a komplexitás jellegzetességeiböl és annak szükséges kezeléséböl/menedzseléséből vezetem le. 


\section{Az állami szerepvállalásról röviden}

Az állami feladatok azon közfeladatok, amelyeket a legföbb szuverén - általában politikai meggyőződésből - magára vállal (Pétervári, 2004). A végrehajtó hatalmak felhatalmazásaik révén egyre több és összetettebb funkciókat láthatnak el, amelyeknek a rendszerezése, együttes értelmezése (interdependenciák tetten érése, holisztikus szemlélet), átlátása már önmagában is nagy kihivást jelenthet. Az állami feladatok egyre terebélyesedő halmazában eltérő megközelítésủ és szempontrendszerü funkcionális csoportok képezhetőek. Az OECD például az SNA logikảjából levezetve osztályozza a kormányzati közkiadásokat: 10 föcsoportba (first level) és további alcsoportokba (second level), amelyek a legföbb funkcionális területeket részletezi tovább (Ezt nevezzük COFOG besorolásnak - Classification of the Functions of Government) (OECD, 2013). Az alábbi föcsoportokat nevesitik: (1) általános közszolgáltatások, (2) védelmi funkciók, (3) közrend és biztonság, (4) a gazdaság szabályozása, (5) környezetvédelem, (6) lakhatás és közösségi rekreáció, (7) egészségügy, (8) egészségmegörzés, kultúra és vallásügy,(9) oktatás, valamint (10) társadalombiztosítás. Az elmélet szerint a központosítás és az újraelosztás révén olyan problémák, helyzetek megoldása, illetve olyan értékek elöállítása történhet meg a közszférában, amely a piaci kudarcok hatásainak csökkentését, leküzdését célozzák meg vagy pedig olyan feltételeket, keretrendszert teremt és müködtet, amelyben a közösség számára bizonyos kedvező hatások, szinergiák jobban kiteljesedhetnek (és/vagy a kedvezőtlen jelenségek, mintázatok csillapitása, kontroll alatt tartása, visszaszoritása), mint az állami beavatkozás nélküli állapotban. Nagyon egyszerüen fogalmazva ez azt jelenti, hogy ezek a funkciók alapvetően a közjó előmozdítását célozzák meg.

Mindezek a tevékenységek az elvárások és a lehetőségek (rendelkezésre álló erőforrások) által lehatárolt - gyakorta szükülő - mozgástérben zajlanak. A precízebb, intelligensen célzott és eredményesebb beavatkozásokhoz figyelembe kell vegyük, hogy a közpénzügyi döntéseinkre ható környezet (belső elvárások, külső determinációk) és a kompetitív, valamint a közszektor értékteremtési folyamatainak színtere egyre összetettebbek; szupranacionálisan, sôt globálisan egyre kiterjedtebb hálózatban értelmezhető (Kaul és Conceição, 2006); a kormányzati fiskális és értékválasztásokat, elköteleződéseket egyre több szempontból szükséges értékelni a (kiterjesztett) fenntarthatósági kritériumoknak alárendelve. A fenntarthatóság köztudatban is megtalálható vetületei a környezeti, gazdasági és a társadalmi kiegészül a kulturális, közpénzügyi, elszámoltathatósági és a törvényességi/legitimációs fenntarthatósággal.

\section{A közpénz tradicionális megközelítése}

Az állami szerepvállalás fontossága és a közpénz szerepe, funkciói már korábban is a tudományos érdeklődés látómezejébe került. Plehn (1902) már a huszadik század közvetlen elején összegezte az akkori legmodernebb nézeteket a közösségi finanszírozás létjogosultságáról. A könyv olvasása közben szinte alig hihető annak kora gondolatiságának ismeretében. Ennek két magyarázata is lehet: (1) a tartalom és a szemlélet nagyon elöremutató, vagy (2) a közpénzügyekkel foglalkozó könyvek alapvető logikája nem sokat változott azóta, csupán a kor aktuális kérdéseit nagyítják fel. A közpénzügyeket tudományként és müvészetként aposztrofálja, a közpénzügyi menedzserek/döntéshozók olyan tevékenysége, amely eszközöket rendel az állami funkciók ellátásához. (Tudományként szoros összefüggésbe hozza a politológióval és a politikai gazdaságtannal.)

A funkciók ellátása (hasznosulása) az államhatalom létfenntartását is alátámasztják (legitimáció). Véleményéből erősen kikristályosodik, hogy az államháztartási rendszer léte és 
müködése meghatározó tényezője lehet a „nemzetek gazdagságának”; a közpénzeknek ebben az összefüggésben mindenképp közösségi érdekeket kell szolgálnia (a szerző itt utal Adam Smith munkásságára). Mind a bevételi, mind a kiadási oldalt relevánsnak gondolja, annak ellenére, hogy akkoriban az adóztatási kérdések élveztek nagyobb odafigyelést. A jövedelmek elvonását és újraelosztását indokoltnak érzi abban az esetben, ha ennek következményeként vagyon és értékteremtődés valósulhat meg az adott gazdaságban. Mindezt a következőképpen fogalmazza meg:

„Közpénzügyekrôl azóta beszélhetünk, amióta az uralkodó és az állam/kormány jövedelme elkülönül - azaz amint bármilyen direkt/közvetlen adó a polgárok jólétének érdekében lettek kivetve, vagy bármifajta vagyonkezelés/vagyongazdálkodás, hogy olyan bevételeket biztosítson az elismert közcél érdekében; mindez több, szélesebb körü, mint a királyi udvar fenntartása." (Plehn, 1902: 4)

Írásából - mai szemmel nézve - kiviláglik a komplex tervezési környezetre való utalás. Jobb és eredményesebb kormányzati szervek létrehozását sürgeti, amelyek az egyre összetettebb ipari, kereskedelmi és társadalmi szervezeteket, szerveződéseket szolgálnak ki és hangolják össze azok tevékenységeit. Az államot egy olyan szervezetként azonosítja, amelybe a személy beleszületik (vagy ennek analógiáján, amelyben a szervezet létrejön vagy odatelepül), és ami által remélheti a legnagyobb mértékü saját fejlődését. Ez a gondolat már előrevetíti a komplexitás kezelésének modern felfogását: képessé tevő, intelligens alkalmazkodást lehetővé tevő környezet kialakítása (Plehn, 1902).

$\mathrm{Az}$ állami feladatok ellátása és a közpénz intézménye egymástól elválaszthatatlanok, egyik a másik nélkül nem létezhet. Mindezt a „legitimációs körforgás” jelenségével írhatnám le: közjogi berendezkedés - központosításra való választói felhatalmazás - közösségi értékteremtés folyamatai - (output) legitimáció az újbóli központosításra.

Pétervári $(2004: 16,29)$ alapvetően a magánpénz-közpénz transzformációkra koncentrál és a mindezt formalizáló kötött eljárásokra. Írásában mélyen és alaposan feltárja a közpénz definiálásával kapcsolatos ellentmondásokat, dilemmákat föleg a közpénzügyi rendszer jogi (beleértendö az alkotmányjog is) dimenzióit elemezve. A kormányzatoknak az állami feladatok ellátásához és az ehhez rendel költségvetési elöirányzatok kifizetéséhez két feltételnek kell egyidejüleg teljesülnie: (1) anyagi jogi szabály (a feladat megállapításához és a követendő magatartások tartalmához szükséges) és (2) a költségvetési törvényben megszavazott elöirányzatra, vagyis arra a felhatalmazásra, ami a célokhoz közpénzeket rendel. A közpénz meghatározására az alábbi javaslattal él, amely tartalmazza a szerzö által fontosnak tartott fogalmi elemeket: (1) közszükséglet, (2) eljárási és hatásköri szabályok, (3) elosztási folyamatok és (4) államkincstár.

„Alkotmányos államokban azokat a szabályokat nevezzük alkotmányjogilag a közpénzekkel kapcsolatos szabályoknak, amelyek rögzitik az eljárási és hatásköri szabályokat, és amelyek eligazitanak abban, hogy az illetékes államhatalmi szervek a közvagyonnal miként gazdálkodnak, illetve hogy az általuk megállapitott közszükségletekre az elöre meghatározott összegeket az államkincstár a kitüzött célra miként szedi be, majd osztja szét." (Pétervári, 2004: 32-33).

Vigvári (2010) saját definíciójában a közpénz fogalmát kiterjeszti az állami vagyongazdálkodásból származó jövedelmekre (beleértve az immateriális vagyonelemek is) és az állami szektor hitelfelvételére is, amely források a közjavak és közösségi szolgáltatások elöállítására fordítódnak.

A Sharman-jelentést - amely a brit kormányzat és a parlament közötti elszámoltathatósági relációk átgondolását, újraértelmezését tüzte ki célul az új évezred közvetlen elején - a közpénz értelmezésének kiterjesztéseként fogom fel (Sharman, 2001). A beszámoló számos hiányosságot tár fel, amely a közpénz meghatározása kapcsán elötérbe kerülhet. 
Hangsúlyozzák, hogy nem találtak olyan tartalmilag helyes definíciót, amely munkájukat korrekt módon segítené. A legmagasabb szintü (parlamenti és számvevőszéki) és fejlettebb/minőségibb elszámoltathatóság iránti igényt legfőként azzal indokolják, hogy a közpénz kényszer útján keletkezik (elvonás, központosítás), illetve a közszféra szereplői közötti útja nem feltétlenül nyomon követhető, csak a végső felhasználó azonosítható be. Mivel a közösségi értékteremtésben kevés kényszer generálódik a költségcsökkentés és költséghatékonyság iránt, ezért a számvevőszéki teljesítmény-ellenőrzéseknek nagyobb szerepet kell kapniuk az „értéket pénzért” szemlélet demonstrálásában.

A jelentésben a következő elvek lettek lefektetve: (1) az összes pénz, amelyet egy közszférában tevékenykedő szervezet (testület) kap, függetlenül annak forrásától, közpénz! (2) minden olyan pénz, amely közszférából (szervezettől) érkezik a nem-közszférabeli szervezethez, közpénz! (3) és mindezekhez kiegészítésül, hogy a közszférára vonatkozó elszámoltatási rendszer (public financial accountability) (azok szabályaival, következményeivel együtt) érvényesnek kell lenni (alkalmazhatóvá kell tenni) a magánpénzekre is, abban az esetben, ha törvényi felhatalmazás alapján keletkezik ( $k o ̈ l t i k ~ e l$ ), vagy ha a kérdéses szervezet a helyi közkiadások szempontjából érintett (Heald és McLoad, 2002; Sharman 2001).

\section{Komplexitás és a közpénzügyi vonatkozásai}

A közpénzügyi rendszer valós környezete és önmaga is komplex adaptív rendszerként írható le. Ezekre többek között az alábbiak jellemzőek (Kaisler és Madey, 2009; Dinya, 2008; Mérő, 2007):

- (relatíve) sok elemböl, ágensböl, entitásból épülnek fel, amelyek strukturált elrendeződésben figyelhetőek meg, illetve bizonyos hálózati, hierarchikus csoportokba (például klaszterekbe) rendeződve funkcionálnak

- a struktúrák elrendeződése, felépitése dinamikát kölcsönöz a rendszer egészének, a folyamatok sokszor nemlineárisak, tehát kis változás az input oldalon markáns változásokat generálhat a kimenetelben vagy nagy változás akár változatlanul hagyhatja az outputot - a rendszer „elnyeli" az öt érő impulzust

- sokszor váratlan, elöre nem látható, extrém (kis bekövetkezési valószínüségü) jelenségek is tapasztalhatóak

- a szerkezeti, rendszerszintü állapotváltozások folyamata nem írható le egyetlen egyszerü szabállyal vagy nem egyszerüsíthetö le egyetlen szintü és szempontú magyarázatra

- az ágensek (ki)hatnak egymásra, kapcsolatba kerülnek egymással, egyénileg (saját önérdeküknek alárendelve) alkalmazkodnak, illetve sikertelen adaptáció esetén kiszelektálódnak (a közszférában a szelekciós nyomás kevésbé intenziven jelentkezik, mint a versenyszektorban, ami kihatással lehet a közösségi értékteremtés hatékonysági kérdéseire is)

- a komplex rendszerek gyakori jellemzöje az „emergence”, az interakciókból, viselkedési formákból kialakuló rendszer- vagy makroszintü jellemzők/mintázatok, amelyeket az önszerveződö folyamatok alakítanak ki, de a mikro- vagy ágensszintü vizsgálódással nem magyarázható, a megjelenő mintázatok mögött nagyon egyszerü vezérlőelvek húzódnak meg

- Az önszerveződés folyamata (self-organization) akkor indul be, amikor a szereplök a megfelelőbb alkalmazkodási lehetőségek keresik - önérdekeiknek alárendelve - külső vagy belső adaptív nyomásnak/feszültségnek engedve (Boisot és McKelvey, 2011). 
- A káosz pereme (edge of chaos): Ekkor a rendszer a rend és a káosz közötti tartományban müködik. Ekkor a legerösebbek az adaptív képességek. Az egyensúlyban lévö rendszernek nincs meg az a belső dinamikája (adaptivitásra irányuló kényszer itt hiányzik!), hogy a külső változásokra reagáljon, elöbb vagy utóbb így megszünik létezni; a káoszban müködö rendszer pedig alapvető funkcióit nem tudja ellátni. A káosz peremterületén lévö rendszer képes produkálni a legjobb válaszokat, a kellö kreativitást és változatosságot a megfelelö, leghatékonyabb alkalmazkodást, amelyet hosszú távon is képes így fenntartani.

- a komplex rendszerek integráltságából fakadóan számos nézőpontból vizsgálhatóak és különböző mérési skálákat alkalmazhatunk (pl.: atomok - sejtek - a szervek rendszere - az emberi test - a társadalom, illetve a fenntartható fejlődés értelmezése kapcsán a fenntarthatósági dimenziók egymásba ágyazódása: környezeti, gazdasági, társadalmi, kulturális, közpénzügyi és szabályozói vetületek)

- korlátozott racionalitás, a holisztikus szemlélet hiánya (nem áll rendelkezésre a „big picture" a szabályozók, döntéshozók számára) és a nem egységesen értelmezett fogalmak (lásd például a közjó, vagy a közpénz fogalma) a transzparenciát és egyértelmüséget korlátozhatják; a rendszerben található visszacsatolási mechanizmusok a tanulási folyamatokat indukálhatnak és erősíthetnek fel.

A közpénzek kezelése és a közpénzügyek menedzselése az egyre bővülő állami feladathalmaznak és a „turbulensen" változó müködési környezetnek/közegnek köszönhetően a döntéshozóknak, közpénzügyi menedzsereknek egyre inkább szembe kell néznie a komplexitás kezelésének igényével. A komplexitás menedzselése és a közszféra kapcsolata az elmúlt pár évben különösen dinamikusan fejlödő terület lett a szakirodalomban (Cairney, 2012; CIPFA, 2013; Dolphin és Nash, 2012; Duit és Galaz, 2008; Duit et al., 2010; Gilpin és Murphy, 2008; Jones, 2011; Kaul és Conceição, 2006; Kovács, 2014; Nooteboom és Termeer, 2013; Swanson és Bhadwal, 2009). A komplex környezeti jelenségek, komplex szervezeti válaszreakciókat kívánnak a hatásos beavatkozásokért, a fenntartható adaptációs képességekért. Írásom szükre szabott keretei miatt a továbbiakban csak a közpénz funkciót vizsgálom a nemlineáris szemlélet tükrében.

\section{A közpénz és a komplexitás}

A magánpénz-közpénz-magánpénz állandó transzformációja különösen érdekessé teszi ennek a vizsgálatát - föleg akkor, ha mindez komplex rendszerekben zajlik. Amennyiben a közpénzügyi rendszerre tekintünk, akkor a komplexitás jellemzöi mind a bevételi, forrásszerzési oldalt, mind pedig a közfinanszírozás által megvalósuló közösségi értékteremtést érinti. A komplexitás kezelésének, menedzselésének ugyanakkor a kormányzati feladatkörökbe kellene tartozniuk. ( $A z$ új szemlélet tükrében elvárható kormányzati funkciók és a komplexitás dinamikájából levezethetö közjó tárgyalása nem része jelen tanulmánynak.) Az átértékelödött, újradefiniált feladatkörök, az új vezetési, szervezési paradigma a korábbi definíciók átgondolását is maguk után vonják.

A kellö mértékü közpénz feletti rendelkezés, döntési lehetőség együtt járhat hatalom gyakorlásával és befolyás kiépítésével (Pétervári, 2004). A közpénzek megszerzése iránti akarat, vágy adaptív nyomásként azonosítható be. A komplex rendszerekben mindez olyan folyamatokat indíthat el, amelyek az önérdek által vezéreltek és olyan viselkedési mintázatok alakulhatnak ki az ágensek közötti interakciókból, amelyek a közjó kiteljesedését akadályozhatják és a társadalom egészére káros lehet. Ilyenek lehetnek a korrupciós jelensé- 
gek, járadékvadász magatartás, íratlan szabályok megjelenése és követése, téves/illuzórikus visszacsatolási folyamatok (Báger, 2013). Ebben az értelemben a közpénz Janus-arcú: egyszerre lehet a közjó szolgálója, a fenntartható fejlödés és jólét megteremtésének finanszírozója, ugyanakkor a társadalmi „vadhajtások” táptalaja, az újratermelődő államadósságok, a téves finanszírozási döntések révén pedig a társadalmi innováció, adaptivitás megakasztója.

\section{A közpénz funkcióinak szintetizálása, összefoglalás}

A korábbiakban röviden áttekintettem a közpénz meghatározásának megközelítéseit és fogalmi elemeit. Szó esett a költségvetés bevételi és kiadási oldaláról, az ellátandó állami feladatokról, a magánpénz-közpénz transzformációjáról és a közpénz impaktjairól, amelyek a társadalmi-gazdasági hálóban fejtik ki hatásukat. Már maga a magánpénz is a közbizalom hordozója, és végeredményben a végső (ultimate principal) felhatalmazó/megbízó azaz a választópolgár által megválasztott törvényhozó és végrehajtó hatalom ruházza fel hivatalos csereeszközzé, illetve alkot olyan törvényi hátteret, keretrendszert, amelyben hitelpénzt lehet teremteni. Természetesen a hitelpénzek megteremtésére, kezelésére és a rájuk vonatkozó követelésekre gyakran kiterjesztik az állami kontrollt és felügyeletet. A közpénzekre vonatkozó szabályok, döntési mechanizmusok, törvényi felhatalmazások ezzel párhuzamosan sokkal kötöttebbek és átláthatóságuk is nehézkesebb.

\section{A közpénz funkciói és jellemzöi:}

- szakpolitikák megvalósításának eszköze

- államháztartási rendszer likviditásának biztosítása

- közösségi felhatalmazás révén a gazdasági és egyéb érdekek terelésének az eszköze, egyfajta befolyásolási eszköz

- a bürokratikus koordináció kelléke

- rövid-hosszú távú érdekrendszer közti transzformáció segítöje (intertemporális választások a közjó érdekében) (Kovács, 2010, 2014)

- állami funkciók ellátását és delegálását teszi lehetővé

- a költségvetési tervezés révén az állami feladatok beárazásának eszköze, amely az összehasonlitást és a pénzügyi ellenőrzést is megkönnyíti

- a közpénzek megszerzése kapcsán a gazdasági szereplök erősen motiváltak, ugyanakkor a közpénzek birtoklása vagy a felette való rendelkezés hatalmat jelenthet, elkényelmesít és az innovációs kényszert csökkentheti (motiváló és elkényelmesítő egyben)

- a megbizó-ügynök relációban megbizási problémát generál (a megbízott viselkedését, hozzáállását megváltoztathatja)

- a közpénzekre vonatkozó (törvényi vagy alkotmányos alapokon nyugvó) elszámoltathatósági folyamat révén, annak végeredményeként ex post információt szolgáltat a gazdaság szereplöi számára

- Janus-arcúság

- nincs közvetlen, kézzelfogható megnyilvánulása (nem készpénz), csak az eredményei láthatóak, absztrakt formában létezik, a „virtualitása” csökkenti a közvetlenség érzetét

- közpénzekkel kapcsolatos döntések garanciáját jelentheti az államhatalmi szervek döntési jogosultságainak szeparálása (Pétervári, 2004)

- a közpénzek keletkezésének, felhasználásának, hasznosulásának belső és külső ellenörzési mechanizmusai vannak, amelyek a közszférába vetett bizalmat erösíthetik 
- A közpénzekkel kapcsolatos folyamatok törvényességi, szabályszerüségi megfelelöségéről, a felhasználásuk gazdaságosságáról, eredményességéről és hatékonyságáról, valamint az impaktok a számvevőszék objektív, minőségi információkat biztosít

A közpénz a közpénzügyi rendszer meghatározó eleme: keletkezése, transzformációja, megszerzése, kezelése, felhasználása szigorú alkotmányos és törvényi szabályozás és a közpénzügyi elszámoltathatóság felügyelete alatt áll. Az államhatalom felhatalmazásai révén jogosult a magánpénzeket közpénzekké alakítani a közjó megvalósításának indokoltságával. Mivel a közösségi értékteremtés komplex adaptív rendszerekben zajlik, így nem kívánatos, a közjó szempontjából káros jelenségek is kialakulhatnak. A közpénz megszerzésére irányuló erős motivációk olyan viselkedési mintázatokat indukálhatnak (korrupciós tevékenységek, járadékvadászat), amelyek a társadalmi, gazdasági innovációkat, kreativitást, intelligens alkalmazkodóképességet visszavethetik. A közpénzügyi ellenörzés (legyen az külsö vagy belsó) egyik fontos feladata, hogy ezeket a jelenségeket feltárja és a gerjesztésüket tápláló visszacsatolási folyamatokat megszüntesse.

\section{Irodalomjegyzék}

Báger G. (2013): Korrupció: büntetés, integritás, kompetencia. Akadémiai Kiadó, Budapest.

Boisot, M., McKelvey, B. (2011): Complexity and Organization-Environment Relations: Revisiting Ashby's Law of Requisite Variety. In: Allen, P., Maguire, S., McKelvey, B. (szerk.): The SAGE Handbook of Complexity and Management $16^{\text {th }}$ Chapter. SAGE Publications, London, 279-299.

Cairney, P. (2012): Complexity Theory in Political Science and Public Policy. Political Studies Review, 10 (3), 346-358.

CIPFA (2013): Public finances: at the edge of chaos and ready for outcomes? The CIPFA Conversation, The Chartered Institute of Public Finance \& Accountancy.

Dinya, L. (2008): Szervezetek sikere és válsága. Változatlan utánnyomás, Akadémiai Kiadó, Budapest.

Dolphin, T., Nash, D. (szerk.)(2012): Complex New World - Translating new economic thinking into public policy. Institute for Public Policy Research, London.

Duit, A., Galaz, V. (2008): Governance and Complexity - Emerging Issues for Governance Theory. Governance: An International Journal of Policy, Administration, and Institutions, 21 (3), $311-$ 335.

Duit, A., Galaz, V., Eckerberg, K., Ebbesson, J. (2010): Governance, Complexity, and Resilience. Global Environmental Change, 20 (3), 363-368.

Gilpin, D. R., Murphy, P. J. (2008): Crisis management in a Complex World. Oxford University Press, Oxford.

Heald, D., McLoad, A. (2002): Public Expenditure. Constitutional Law, 2002, The Laws of Scotland: Stair Memorial Encyclopaedia, Edinburgh, Butterworths, para 483.

Jones, H. (2011): Taking responsibility for complexity - How implementation can achieve results in the face of complex problems. Working Paper 330, Overseas Development Institute, London.

Kaisler, S. H., Madey, G. (2009): Complex Adaptive Systems: Emergence and Self-organization. Elöadás anyaga, HICSS-42, Big Island USA, HI. January 5, 2009.

Kaul, I., Conceição (szerk.)(2006): The New Public Finance - Responding to Global Challenges, Overview. Oxford University Press, Oxford.

Kovács Á. (2010): Közpénzügyek. ELTE Eötvös Kiadó, Budapest.

Kovács Á. (2014): Vázlatos betekintés a közpénzügyi döntéshozatalba. Oktatáskutató és Fejlesztő Intézet, Budapest.

Mérö L. (2007): A pénz evolúciója. Tericum Kiadó, Budapest.

Nooteboom, S. G., Termeer, C. J.A.M. (2013): Strategies of Complexity Leadership in Governance Systems. International Review of Public Administration, 18 (1), 25-40. 
Pétervári K. (2004): Közpénzek - magánpénzek avagy a számvevõszéki ellenörzés alkotmányjogi problémái. Gondolat Kiadó, Budapest.

Plehn, C. C. (1902): Introduction to Public Finance. $2^{\text {nd }}$ edition, The McMillan Company, New York.

OECD (2013): Government at a glance. Organization for Economic Co-operation and Development, Paris.

Sharman, C. (2001): Holding to Account - The Review of Audit and Accountability for Central Government. Report by Lord Sharman of Redlynch.

Swanson, D., Bhadwal, S. (szerk.) (2009): Creating Adaptive Policies - A Guide for Policy-making in an Uncertain World. SAGE Publications, London.

Vigvári A. (2010): Pénzügy(rendszer)tan. Akadémiai Kiadó, Budapest. 